\title{
Trichomonas gallinae infections in the naïve host Montifringilla nivalis subsp. nivalis
}

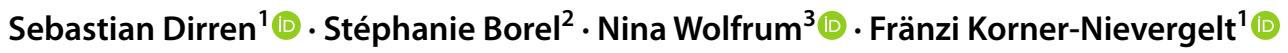

Received: 7 May 2021 / Revised: 11 October 2021 / Accepted: 26 October 2021 / Published online: 8 November 2021

(c) The Author(s) 2021

\begin{abstract}
Infectious diseases bear a great risk for populations of naïve host species. In the present article we inform about the first microscopic and molecular detection of the bird pathogen Trichomonas gallinae in the White-winged Snowfinch (Montifringilla nivalis subsp. nivalis). The emergence of trichomonosis in this highly specialised alpine bird species may pose a serious threat to its already declining population. Interspecies transmission of $T$. gallinae most likely occurred at a bird feeder in a Swiss mountain village. Monitoring of the disease and immediate measures to prevent its spread are urgently needed.
\end{abstract}

Keywords Trichomonas gallinae $\cdot$ Snowfinch $\cdot$ Montifringilla nivalis $\cdot$ Breeding population decline $\cdot$ High-elevation specialist $\cdot$ Epidemic $\cdot$ Bird feeder $\cdot$ Disease

\section{Zusammenfassung}

\section{Trichomonas gallinae Infektionen bei der naiven Wirtsart Montifringilla nivalis subsp. nivalis}

Übertragbare Krankheiten bergen ein hohes Risiko für Populationen von naiven Wirtsarten. In diesem Artikel publizieren wir den ersten mikroskopischen und molekularen Nachweis von Trichomonas gallinae als Erreger der Trichomonadose beim Schneesperling (Montifringilla nivalis subsp. nivalis). Die Krankheit stellt eine potentielle und ernstzunehmende Gefahr für die aktuell abnehmenden Populationen der hoch spezialisierten alpinen Vogelart dar. Unsere Ergebnisse legen nahe, dass es zu einer Übertragung von T. gallinae von Gartenvögel auf den Schneesperling in einem Schweizer Bergdorf gekommen ist. Sofortige Maßnahmen zur Verhinderung von Ansteckungen sowie eine Überwachung der Ausbreitung von T. gallinae sind dringend nötig.

Communicated by I. Moore.

Sebastian Dirren

sebastian.dirren@vogelwarte.ch

Stéphanie Borel

stephanie.borel@vetsuisse.unibe.ch

Nina Wolfrum

nina.wolfrum@uzh.ch

Fränzi Korner-Nievergelt

fraenzi.korner@vogelwarte.ch

1 Swiss Ornithological Institute, Seerose 1, 6204 Sempach, Switzerland

2 Centre for Fish and Wildlife Health of the University of Bern, Laenggassstrasse 122, 3012 Bern, Switzerland

3 National Reference Centre for Poultry and Rabbit Diseases (NRGK), Institute for Food Safety and Hygiene, Vetsuisse Faculty, University of Zurich, Winterthurerstrasse 270, 8057 Zurich, Switzerland

\section{Introduction}

Host switches from one species to another have been reported for many avian pathogens (Marzal et al. 2011). The outcome of such an interspecies transmission depends on multiple factors like the pathogen's virulence, the capacity of the host immune system to cope with the infectious agent, the efficiency of transmission and numerous environmental parameters influencing the physiological condition of the pathogen and the host. Consequences for newly infected species can thus hardly be assessed right after a spill-over event. In unfavourable cases naïve hosts face the emergence of an infectious disease. While it is the nature of emerging infectious diseases (EIDs) to pose a serious threat for the health of bird populations, in a handful of cases they might even drive species into decline and towards extinction (Daszak et al. 2000; Lawson et al. 2018). Small populations of endemic species are especially threatened by EIDs. For 
example, avian pox and malaria likely played a major role in the extinction of several Hawaiian honeycreeper species (Atkinson and LaPointe 2009).

The flagellated protozoa Trichomonas gallinae (Rivolta 1878) is known since the end of the nineteenth century as a pathogen of birds (Stabler 1947). Infections with T. gallinae are referred to as trichomonosis typically causing yellow lesions located in the oral cavity, eyes, skull, pharynx, oesophagus and crop (Martínez-Herrero et al. 2020). The severity of the disease ranges from no clinical signs to multifocal lesions with ulcerations and/or systemic infections. Obstructions of the oesophageal/pharyngeal lumen interfering with food intake and breathing may be fatal even at an early stage of the disease (Stabler 1947). Trichomonas gallinae is mainly known from columbids and their predators. While pigeons and doves were found to have high prevalence of T. gallinae (i.e. $44.8 \%$ ), less than $1 \%$ of infected individuals showed clinical signs (Sansano-Maestre et al. 2009). In contrast to this outnumbering of subclinical infections, trichomonosis was pinpointed as a major mortality factor for the endemic and endangered Pink Pigeon (Nesoenas mayeri) on Mauritius (Gaspar da Silva et al. 2007). These findings indicate that susceptibility to infections with $T$. gallinae varies among bird species. On the other hand, distinct strains of T. gallinae differ in their virulence (Sansano-Maestre et al. 2009). Sequencing of three genetic markers, the $18 \mathrm{~S}$ rRNA gene, the ITS1/5.8S rRNA/ITS2 region, and the Fe-hydrogenase gene, has been mainly used for molecular characterisation (Gaspar da Silva et al. 2007; Sansano-Maestre et al. 2009; Lawson et al. 2011; Ganas et al. 2014; McBurney et al. 2015; Chavatte et al. 2019; Rijks et al. 2019; MartínezHerrero et al. 2020). Depending on the marker and whether single locus or multi-locus approaches are used, differentiation down to the species or even strain level is possible.

First cases of trichomonosis in songbirds were reported from Greenfinches (Carduelis chloris) and Chaffinches (Fringilla coelebs) in Great Britain (GB) in 2005 (Lawson et al. 2018). The following year the disease already caused epidemic outbreaks. Trichomonas gallinae was subsequently identified as the aetiologic agent of a novel EID in passerines, which was responsible for a continuous population decline in greenfinches of $66 \%$ between 2006 and 2016 in GB (Lawson et al. 2018). While the pathogen was also detected in other passerines, impact on populations was much lower for these species compared to greenfinches and chaffinches. The high susceptibility of finches in general is not restricted to Europe but New World fringillid species like the House Finch (Carpodacus mexicanus), the Purple Finch (Carpodacus purpureus) and the American Goldfinch (Carduelis tristis) are similarly affected (Anderson et al. 2010; McBurney et al. 2015). In Europe, a progressive spread of trichomonosis was documented. While in 2006, mortality of finches was greatest in western and central counties of
England and Wales, the disease first spread to eastern England in 2007 and to Fennoscandia in 2008. It is believed that migrating birds (i.e. chaffinches) acted as carriers spreading the diseases to the mainland of Europe (Lawson et al. 2011). Later, local outbreaks of trichomonosis were reported from the Netherlands and northern Germany in 2009 (Peters et al. 2009), central and western France in 2010 and 2011 (Chavatte et al. 2019), respectively, Austria and Slovenia in 2012 (Ganas et al. 2014) and northern France in 2017/2018 (Peters et al. 2009).

In the present article, we report the first detection of trichomonads in a formerly unaffected bird species belonging to the family Passeridae, namely the White-winged Snowfinch (Montifringilla nivalis subsp. nivalis; hereafter referred to as 'snowfinch'). The snowfinch is highly adapted to the alpine environment, even enduring harsh winter conditions at elevations above $2000 \mathrm{~m}$ a.s.l. (Heiniger 1991). The subspecies has a disjunct breeding range above the treeline in the Cantabrians, the Pyrenees, the Alps, Corsica, the Apennines, and in the mountains of southwestern Balkans. Highly specialised alpine species, such as the snowfinch, are especially prone to suffer from habitat changes caused by climate warming (Resano-Mayor et al. 2019). Such changes might thus be a major factor for the negative population trends generally monitored throughout Europe. In Switzerland (harbouring 15\% of the world population, see Keller et al. 2010), the number of snowfinches decreased over the past three decades by about one-third (Fig. S1).

\section{Methods}

In March 2019, diseased snowfinches and later dead individuals were observed at a bird feeder in Arosa, Switzerland (coordinates: $46.773^{\circ} \mathrm{N} 9.655^{\circ} \mathrm{W}$ ). The carcass of one of these birds (collection date: 21.03.2019) was sent for routine post-mortem examination to the Centre for Fish and Wildlife Health (FIWI) of the University of Bern. The standard diagnostics included full gross and microscopic examinations as well as the detection of Salmonella spp. but no testing for avian influenza, as there was no evidence of an acute outbreak in the region at the time of sampling. Formalinfixed paraffin-embedded (FFPE) material enabled molecular characterisation of the pathogen. DNA was extracted from the FFPE tissue using the ReliaPrep ${ }^{\mathrm{TM}}$ FFPE gDNA Miniprep System (Promega). PCR amplification of the ITS1/5.8S rRNA/ITS2 locus as well as the Fe-hydrogenase gene and subsequent sequencing was performed as described elsewhere (Gaspar da Silva et al. 2007). 
Table 1 Results of postmortem examinations of Swiss greenfinches

\begin{tabular}{llllll}
\hline Year & $\begin{array}{l}\text { Number of green- } \\
\text { finches }\end{array}$ & $\begin{array}{l}\text { Trichomonosis } \\
\text { suspected }^{1}\end{array}$ & $\begin{array}{l}\text { Trichomonosis } \\
\text { evident }^{2}\end{array}$ & $\begin{array}{l}\text { Salmonella sp. } \\
\text { detected }\end{array}$ & $\begin{array}{l}\text { Other diseases } \\
\text { (incl. trauma) }\end{array}$ \\
\hline 2010 & 2 & - & - & 1 & 1 \\
2011 & - & - & - & - & - \\
2012 & 9 & $1^{3}$ & 7 & - & 1 \\
2013 & 3 & - & 3 & - & - \\
2014 & 7 & - & 7 & - & - \\
2015 & 2 & - & 2 & - & - \\
2016 & 2 & 0 & 2 & 0 & 0 \\
2017 & 0 & 0 & 0 & 0 & 0 \\
2018 & 1 & 0 & 0 & 0 & 1 \\
2019 & 10 & $2^{4}$ & 8 & 0 & 0 \\
\hline
\end{tabular}

All greenfinches examined between 2010 and 2019 by the Centre for Fish and Wildlife Heath of the University of Bern are listed. The manner of death for all these birds was exitus

${ }^{1}$ Characteristic lesions (i.e. pharyngitis, oesophagitis and/or ingluvitis) and absence of Salmonella sp.

${ }^{2}$ Observation of Trichomonas sp. by microscopy, characteristic lesions (i.e. pharyngitis, oesophagitis and ingluvitis) and absence of Salmonella sp.

${ }^{3}$ This bird was treated before its exitus with the antiprotozoal drug Spartrix

${ }^{4}$ Characteristic lesions but missing bacteriological analysis due to autolysis of tissue

\section{Results and discussion}

In 2012, first cases of trichomonosis in greenfinches were detected by the FIWI (Table 1). After first detection in Swiss greenfinches local outbreaks became a reoccurring phenomenon (Table S1). Trichomonosis most likely contributed to the strong decline (i.e. $40 \%$ on the national level) of greenfinches over the subsequent years (Knaus et al. 2018). Several studies confirmed the aetiologic agent of trichomonosis in European passerines to be a clonal strain of T. gallinae, i.e., the A1 strain (Ganas et al. 2014; Lawson et al. 2018;
Chavatte et al. 2019; Rijks et al. 2019). Introduction of this epidemic strain likely led to the spread of trichomonosis among Swiss greenfinches.

In March 2019, high morbidity and more than 20 dead snowfinches were reported from a bird feeder in the mountain village Arosa. The bird for which post-mortem examination was performed was in poor body condition with no fat reserves and attenuated wing muscle (Fig. 1a). Thickening of the mucosa and yellow plaques were observed in the oral cavity, cranial region of the oesophagus and crop (Fig. 1b). Histological examination of the tissue showed extensive erosions and ulcerations with accumulations of necrotic cell
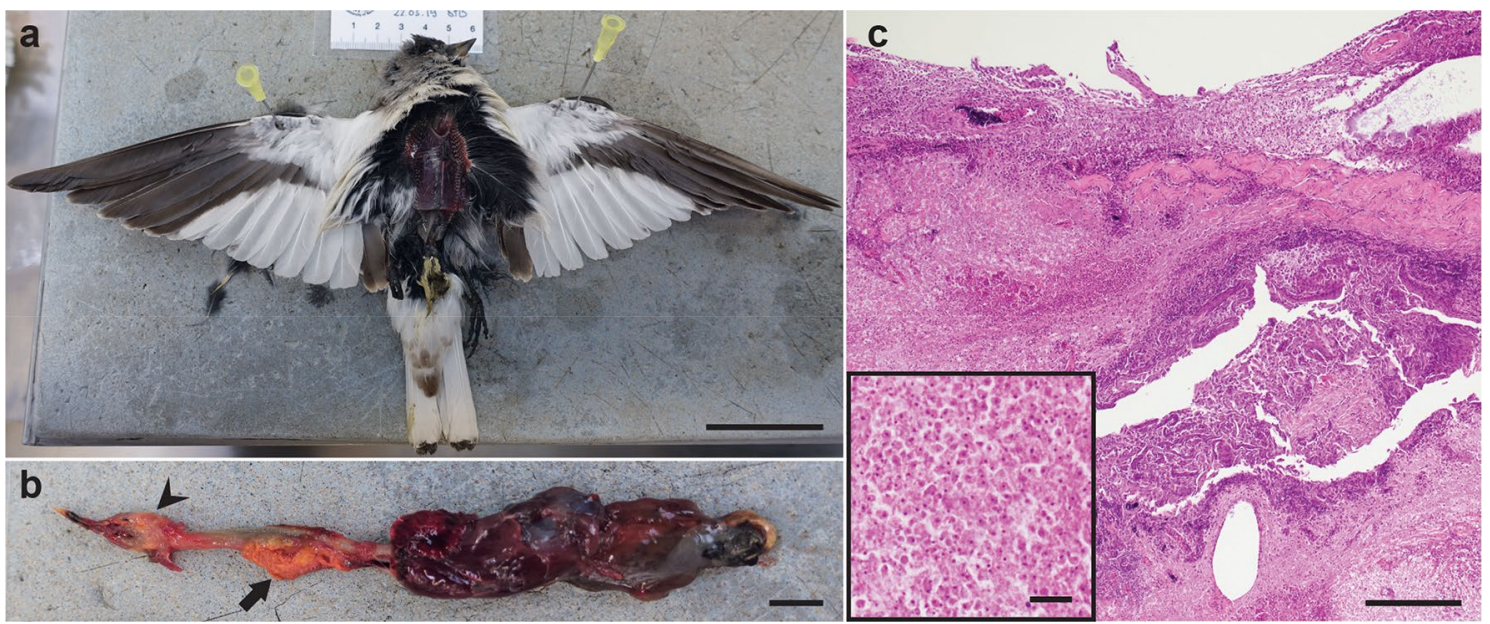

Fig. 1 Post-mortem examination of the snowfinch specimen revealed $\mathbf{a}$ attenuated pectoral muscles indicative of emaciation, $\mathbf{b}$ oral (arrow head) and esophageal (arrow) caseonecrotic lesions and $\mathbf{c}$ transmural necrosis of the esophageal wall with intralesional numerous oval to round, pale, eosinophilic protozoa $(6-8 \mu \mathrm{m})$ with small, basophilic nuclei $(2 \mu \mathrm{m})$, consistent with Trichomonas sp. (inset). Size bars represent $5 \mathrm{~cm}$ in (a), $1 \mathrm{~cm}$ in (b) and $200 \mu \mathrm{m}(20 \mu \mathrm{m}$ in inset) in (c) 
debris (Fig. 1c). Viable and degenerated inflammatory cells were observed, together with oval to round, pale, eosinophil protozoa $(6-8 \mu \mathrm{m})$ with a small, basophilic nucleus $(2 \mu \mathrm{m})$. Based on morphological features, they were tentatively identified as Trichomonas sp. (inset of Fig. 1c). Bacterial culture of the oesophagus was negative for Salmonella sp. Taken together, these findings provided evidence that the aetiologic agent of the observed lesions was the detected protozoal organism Trichomonas sp.

Several attempts to amplify the Fe-hydrogenase gene were unsuccessful. In contrast, sequencing of the ITS 1/5.8S rRNA/ITS2 locus resulted in a high-quality sequence of 326 bp (GenBank accession number LR898481). Phylogenetic analysis of the ITS region confirmed the species $T$. gallinae to be the microscopically detected protozoa. Further, the strain could be affiliated with the ITS sequence type 'group A'. This group contains mainly pathogenic strains including the epidemic strain of European finches (Lawson et al. 2018). Even though strain identification was not unambiguous, distribution patterns, pathology and possible ways of transmissions suggested that the epidemic finch-trichomonad strain to be the causative agent of trichomonosis in snowfinches.

Food provisioning may support birds during harsh winter conditions, yet the inherent risk of pathogen transmission should be kept in mind. Infected individuals excessively produce saliva containing trichomonads (Stabler 1947; Lawson et al. 2018). Contaminated food and water are thus a main source for pathogen transmission at bird feeders. Even though snowfinches live above the tree line year round, in winter they may be forced by bad weather periods to seek out foraging grounds at lower elevations. In different areas, groups have learned to visit bird feeders in mountain villages. At these locations flocks of snowfinches get in close contact with typical garden birds. This is in line with our observation of numerous greenfinches regularly visiting bird feeders at $1900 \mathrm{~m}$ a.s.l. in Arosa (i.e. Swiss canton of the Grisons). In fact, one of the two highest breeding records of greenfinches in Switzerland originates from this mountain village (Knaus et al. 2018). Unfortunately, the practice of sending dead birds for post-mortem examinations varies considerably depending on the canton. Between the years 2010-2019 no greenfinches were sent for necropsy from the canton of the Grisons, but trichomonosis was detected in 5 greenfinches collected in the neighbour canton, the canton of St. Gallen (Table S1). A spill-over event in the winter 2018/2019 of T. gallinae from greenfinches (or other garden birds) to snowfinches at a bird feeder in Arosa seems thus likely. To prevent the spread of diseases at feeders, interspecific contact that might not regularly occur in the wild should be minimized and cleaning of feeders should be routine.
Preliminary findings of our study point out the immediate urgency to monitor T. gallinae in snowfinches. The potential risk of trichomonosis for this alpine subspecies with its small global population size and its endemic character is an issue of serious concern. While habitat changes due to climate warming (e.g. altered snow conditions, vegetation and temperatures) likely contributed to the ongoing population decline in snowfinches (Knaus et al. 2018; Resano-Mayor et al. 2019), trichomonosis acts as a novel factor potentially being harmful for the entire subspecies. To assess the impact of the pathogen on the naïve host, it is essential to elucidate distribution patterns of T. gallinae together with population dynamics of snowfinches in different mountains regions. In addition to such basic research, measures preventing the spread of the pathogen should be taken immediately. Hot spots of interspecies transmissions (e.g. bird feeders) should be detected and subjected to rigorous monitoring. This will allow to identify the infectious agent and anticipate outbreaks. Providing information to people feeding birds is an important first measure to prevent the spread of trichomonosis. Future research, which we aim to encourage with the present article, will reveal occurrence patterns of $T$. $\mathrm{gal}$ linae in snowfinches and the impact of trichomonosis on this characteristic species of the alpine environment.

Supplementary Information The online version contains supplementary material available at https://doi.org/10.1007/s10336-021-01938-1.

Acknowledgements We kindly acknowledge Francesco Origgi and Gilberto Pasinelli for their help with the manuscript preparation and Brigitte Sigrist for technical assistance. Further, we thank Becki Lawson for her valuable inputs and suggestions to the proposal of our broader study. Also we thank Herbert Geeser for informing us about the diseased snowfinches and for sending us the carcass.

Funding Open access funding provided by Swiss Ornithological Institute. For financial support, we thank Yvonne Jacob Foundation.

Open Access This article is licensed under a Creative Commons Attribution 4.0 International License, which permits use, sharing, adaptation, distribution and reproduction in any medium or format, as long as you give appropriate credit to the original author(s) and the source, provide a link to the Creative Commons licence, and indicate if changes were made. The images or other third party material in this article are included in the article's Creative Commons licence, unless indicated otherwise in a credit line to the material. If material is not included in the article's Creative Commons licence and your intended use is not permitted by statutory regulation or exceeds the permitted use, you will need to obtain permission directly from the copyright holder. To view a copy of this licence, visit http://creativecommons.org/licenses/by/4.0/.

\section{References}

Anderson NL, Johnson CK, Fender S et al (2010) Clinical signs and histopathologic findings associated with a newly recognized protozoal disease (Trichomonas gallinae) in free-ranging house 
finches (Carpodacus mexicanus). J Zoo Wildl Med 41:249-254. https://doi.org/10.1638/2009-0188R.1

Atkinson CT, LaPointe DA (2009) Introduced avian diseases, climate change, and the future of Hawaiian honeycreepers. J Avian Med Surg 23:53-63. https://doi.org/10.1647/2008-059.1

Chavatte J-M, Giraud P, Esperet D et al (2019) An outbreak of trichomonosis in European greenfinches Chloris chloris and European goldfinches Carduelis carduelis wintering in Northern France. Parasite 26:21. https://doi.org/10.1051/parasite/2019022

Daszak P, Cunningham AA, Hyatt AD (2000) Emerging infectious diseases of wildlife - Threats to biodiversity and human health. Science 287:443-449. https://doi.org/10.1126/science.287.5452.443

Ganas P, Jaskulska B, Lawson B et al (2014) Multi-locus sequence typing confirms the clonality of Trichomonas gallinae isolates circulating in European finches. Parasitology 141:652-661. https:// doi.org/10.1017/S0031182013002023

Gaspar da Silva D, Barton E, Bunbury N et al (2007) Molecular identity and heterogeneity of trichomonad parasites in a closed avian population. Infect Genet Evol 7:433-440. https://doi.org/10. 1016/j.meegid.2007.01.002

Heiniger PH (1991) Zur Ökologie des Schneefinken (Montifringilla nivalis): Raumnutzung im Winter und Sommer mit besonderer Berücksichtigung der Winterschlafplätze. Rev Suisse Zool 98:897-924. https://doi.org/10.5962/bhl.part.79817

Keller V, Ayé R, Müller W et al (2010) Die prioritären Vogelarten der Schweiz: Revision 2010. Ornithologische Beobachter 107:265-285

Knaus P, Antoniazza S, Wechsler S et al (2018) Swiss Breeding Bird Atlas 2013-2016. Distribution and population trends of birds in Switzerland and Liechtenstein, Schweizerische Vogelwarte

Lawson B, Robinson RA, Neimanis A et al (2011) Evidence of spread of the emerging infectious disease, finch trichomonosis, by migrating birds. EcoHealth 8:143-153. https://doi.org/10.1007/ s10393-011-0696-8

Lawson B, Robinson RA, Toms MP et al (2018) Health hazards to wild birds and risk factors associated with anthropogenic food provisioning. Philosoph Transact Royal Soc Biolog Sci 373:20170091. https://doi.org/10.1098/rstb.2017.0091

Martínez-Herrero MC, Sansano-Maestre J, Ortega J et al (2020) Oral trichomonosis: Description and severity of lesions in birds in
Spain. Veterin Parasitol 283:109196. https://doi.org/10.1016/j. vetpar.2020.109196

Marzal A, Ricklefs RE, Valkiūnas G et al (2011) Diversity, loss, and gain of malaria parasites in a globally invasive bird. PLoS ONE 6:e21905. https://doi.org/10.1371/journal.pone.0021905

McBurney S, Kelly-Clark W, Forzan M et al (2015) Molecular characterization of Trichomonas gallinae isolates recovered from the Canadian Maritime provinces' wild avifauna reveals the presence of the genotype responsible for the European finch trichomonosis epidemic and additional strains. Parasitology 142:1-10. https:// doi.org/10.1017/S0031182015000281

Peters M, Kilwinski J, Reckling D, Henning K (2009) Epidemic mortality in greenfinches at feeder stations caused by Trichomonas gallinae - A recent problem in Northern Germany. Kleintierpraxis 54:433-438

Resano-Mayor J, Korner-Nievergelt F, Vignali S et al (2019) Snow cover phenology is the main driver of foraging habitat selection for a high-alpine passerine during breeding: implications for species persistence in the face of climate change. Biodivers Conserv 28:2669-2685. https://doi.org/10.1007/s10531-019-01786-9

Rijks JM, Laumen AAG, Slaterus R et al (2019) Trichomonosis in greenfinches (Chloris chloris) in the Netherlands 2009-2017: A concealed threat. Front Veter Sci 6:425. https://doi.org/10.3389/ fvets.2019.00425

Rivolta S (1878) Una forma di croup prodotta da un infusorio, nei polli. Giornale Di Anatomia, Fisiologia e Patologia Degli Animali 10:149-154

Sansano-Maestre J, Garijo-Toledo MM, Gómez-Muñoz MT (2009) Prevalence and genotyping of Trichomonas gallinae in pigeons and birds of prey. Avian Pathol 38:201-207. https://doi.org/10. 1080/03079450902912135

Stabler RM (1947) Trichomonas gallinae, pathogenic trichomonad of birds. J Parasitol 33:207-213. https://doi.org/10.2307/3273551

Publisher's Note Springer Nature remains neutral with regard to jurisdictional claims in published maps and institutional affiliations. 